\title{
Civic Engagement Index (CEI) - the case of liberal arts universities from Romania
}

\author{
Shahrazad HADAD \\ The Bucharest University of Economic Studies, Bucharest, Romania \\ shahrazad.hadad@fabiz.ase.ro \\ Ramona CANTARAGIU \\ The Bucharest University of Economic Studies, Bucharest, Romania \\ ramona_cantaragiu@yahoo.com
}

\begin{abstract}
We have arrived to a moment in history when the society we are living in is confronted with different sets of problems: hunger, crime, economic crises, natural disasters or cataclysms, and various human rights violations. At the moment the most appropriate way to solve these problems still lies with the organisms of the nation state. As such, the lack of civic sense and the increasing political apathy will only allow these problems to grow out of proportions. We are of the opinion that most of them can be counteracted if we try to educate the civic sense in people. By civic sense or engagement we understand a type of orientation towards being involved in social groups according to democratic principles. It is said the post-socialist countries are particularly threatened by the lack of civic engagement on behalf of their citizens that have reached the point where they take democracy for granted. This is why we explore the role played by universities in developing and shaping this civic attitude amongst young people. In order to do so, we resorted to questionnaires applied in liberal arts universities in Romania. These universities have a special relation to democratic principles, national pride and the perpetuation of the nation state as an ideal for its citizens and because of this we believe they represent a proper starting point for the current investigation. The areas that are targeted through the questionnaire are the following: the academic environment, the methods through which civic values are instilled in the hearts and minds of the students, and the institutional and personal factors that determine faculty to introduce civic values in their academic environments. Using the results we create the Civic Engagement Index (CEI) that can be used as a valuable benchmarking mechanism for those universities that are trying to enhance their civic engagement activities. Finally, we test the hypothesis that certain universities fail to create civic-oriented graduates and we propose ways in which the organizational culture could be transformed into a more supportive one: civic participation guides, civic responsibility classes, and service learning classes for faculty members to increase their openness towards the promotion of civic values.
\end{abstract}

Keywords: civic responsibility, university, civic engagement, liberal arts, Romania.

\section{Introduction to civic responsibility and higher education}

Concerning civil society, Ramalay (2000) has identified how responsibility for building such a society has shifted throughout time: in the eighteenth century, a "good citizen" was a gentlemen, then in the nineteenth century the idea that the majority of associated men are bearers of such responsibilities was introduced, until the twentieth century when the responsibility was in the hands of everyone and no one at the same time. In our vision, in the twenty-first century this responsibility is of each and every individual so it pertains to everyone.

Civic responsibility is seen by researchers as the active participation of the individual in the public life of a community while having as focal point the common good 
(Gottlieb \& Robinson, 2004; Pancer, 2015) and Gauca and Hadad (2013) debate whether civil society can create social entrepreneurs to cater for the needs of people in distress and society at large. Therefore, people with high civic participation rates have positive attitudes towards the communities in which they live and actively give back to them, for example the case rural touristic entrepreneurs (Soare et al., 2017) that contribute to sustainable development (Nastase and Valimareanu, 2017).

PICBE $\mid 1081$

In the study conducted by Thornton and Jaeger (2007), students defined the ideology of civic responsibility as "service to and involvement with the community" (p. 1008). During the study, one faculty participant provided a very comprehensive definition of civic responsibility, definition that managed to capture our attention:

I think [responsible citizenship] requires active engagement and participation in the community and that means that you have an obligation and a duty to work in the best interest of that community even if you have to take an unpopular stance sometimes. It's important that you contribute to your community and think about what's going to be best for everybody in that community, kind of work in that direction.(idem)

Despite that, years ago, public education was mainly concerned with instilling and nurturing the sense of civic responsibility in students (Ontario, 1950), with the years passing this focus has started to lose territory and dilute until today when we are assisting in a reorientation towards good bygone values.

The link between civic responsibility (or responsible citizenship) and universities has come to the attention of the researchers in the last couple of decades. Nevertheless Boyer (1990) has investigated the undertakings of the university as a whole (teachers, students and staff) with respect to civic responsibility. According to Stewart (2012), "[u]niversities have been urged to prepare graduates for successful professional lives and fulfilling lives as civically responsible citizens" (p. 49).

It is very interesting the view point brought by Dewey (1916) who was in favour of community-based experiential learning and democratic citizenship. It meant that learning by doing would help students animate the concepts that they were exposed to during courses. If students are asked to learn beyond memorisation this will lead to a better encoding the information in the long term memory, information that could be more easily retrieved; their experiences and learning happen on a first-hand basis; and they bring contributions to the civil society - they will become more responsible citizens (VanWynsberghe and Andruske, 2007, Korn and Voida, 2015).

The article poses the assumption that universities, beyond their teaching quest, pursue the mission to ultimately shape leaders who can bring large contributions that can enrich the civil society. The challenge of these leaders is to admit that individuals, groups, faculties and organisations do not exist isolated from the community, but rather within the community with which they have to create, develop and maintain a reciprocal beneficial relationship. Therefore civic responsibility is very important for developing leaders. Arguably, society will benefit when undergraduate students become responsible citizens through higher education (Bowen, 1997).

In our opinion the most suited and efficient method of promoting civic responsibility is to embed it in the organisational culture of the university that has come to be assigned new roles in the knowledge economy (Bejinaru, 2017) and even expand in new fields by designing different sets of competencies (Vizitiu et al., 2018). Though countless universities state, either implicitly or explicitly, in their mission statements that their credo is to 
promote civic responsibility, most of them are unimaginably far from being accurate in their objectives. However, we have found that there are universities that have civic engagement so rooted in their DNA that they participate to civic hackathons supported by governments to spur open innovation and bring together professionals into creating innovative solutions for the problems of communities (Johnson and Robinson, 2014). Consultancy companies question the effectiveness of such measures implying that the goals and structures of hackathons need to be properly designed to enable active participation of citizens and not hinder it (HackerNoon, 2017). This is why we decided to thoroughly research into this very sensitive topic.

In The Higher Education and Democratic Culture: Citizenship, Human Rights and Civic Responsibility Declaration (2006), higher education leaders and policy makers affirm their "commitment to democratic principles and practice, [their] conviction is that higher education has an essential role in furthering democratic cultures" (p. 2) as was recognised by 536 college and university presidents in the United States. In a president's declaration on the Civic Responsibility of Higher Education to educate citizens, universities are strategic institutions for the democratic development of societies ergo democratic development revolves around education.

However, in the literature, there are also opposed opinions, for example, Fish (2003a, $2003 \mathrm{~b}, 2003 \mathrm{c}$ ) in several distinct papers has argued that civic engagement as a goal of the academy is at least misguided, if not immoral. According to Kline (2005), "civic education is clearly the contemporary currency of liberal education" (p. 29). Fish (2003) acknowledges the more students know about certain subjects, the more likely they are to become good citizens, and trustworthy citizens (Van Ingen and Bekkers, 2015) but "setting out to form good citizens is a very suspect project" (p. 32) - and he gives three arguments to support his statement: when trying to teach the students moral and civic education, they will deviate from their main purpose which is their academic development; it is simply futile to try to teach civic education because it would not work and the lastly: "1. Faculty, qua faculty, should not take a stand on any political issue. 2. Civic engagement projects involve faculty, qua faculty, taking a stand on political issues. 3. Therefore, faculty, qua faculty, should not conduct civic engagement projects." (p. 32).

As we previously stated, society is confronted with different sets of problems. As opposed to Fish we are of the opinion that most of these problems can be counteracted if we try to educate the civic sense in people. By civic sense or engagement we understand a type of orientation towards being involved in social groups according to democratic principles.

Studying civic responsibility and citizenship in the context of liberal arts requires a view of arts and creative creations as a means to become a member of an imagined national community built on symbolic gestures and artefacts. This imaginary realm offers a place for political contestation, critical dialogue and a repositioning of the self in relation to others in terms of interconnectedness instead of distancing. As a starting point, we took the official mission of each university as an indicative of their positioning in regards to democracy and citizenship: all of the institutions of higher education in Romania state in different terms that their purpose is to help sustain the democratic state and to obey its rules. Thus, at a general level, it seems acceptable to believe that Romanian HEI represent agents of the democratic state through which its means and norms are transferred to future generations of adult citizens. 


\section{Research questions}

The focus of this article is on devising an index for university civic engagement which takes into consideration the interaction between three main types of social actors: the university as an institution, the teaching staff and the students. Each of these social actors interact both with the others and with the external environment (Bratianu and Stanciu, 2010) and internationalization factors (Dima and Vasilache, 2016) and the aggregate result of these interactions gives the level of civic responsibility demonstrated by a certain higher education institution. In the specialised literature for higher education, Thornton and Jaeger (2007) have identified the five most frequently used dimensions of civic responsibility: (a) knowledge and support of democratic values, systems, and processes; (b) desire to act beneficially in community and for its members; (c) use of knowledge and skills for societal benefit; (d) appreciation for and interest in those unlike self; and (e) personal accountability.

\section{Research methodology}

The findings presented in this article are part of a larger study that involves four dimensions: the academic's perception of student involvement in civic duties, the academic's perception of their own identities as civic actors, the universities as institutional sites of civic responsibility, and the conceptual definition of democracy and civic duties held by academics. The research is based on a quantitative survey developed based on a rigorous literature review, an analysis of prominent cases of civic engagement in Romanian universities and personal experiences of the authors who are both engaged in academic teaching. The questions formulated vary from yes or no questions, open-ended ones to multiple choice questions.

In this article, we focus on developing the Civic Engagement Index based on the results obtained from an online-based questionnaire containing 60 questions about the civic responsibility of the universities and five socio-demographic questions. The survey was sent to faculty members belonging to seven Romanian arts universities and faculties (see Table 1) via personalized individual emails or emails addressed to the head of department in those cases in which the contact information for each person was absent from the internet website. The research is still in progress and the analyses presented in this paper are based on a preliminary rate of response of $6 \%$, which we hope to improve by the end of 2018 when the study is set to finish. This article intends to present the model of the Civic Engagement Index and to test if it can be of use for those universities seeking to enhance their local and national presence.

Table 1. Study population - faculty members of Romanian arts universities and faculties

\begin{tabular}{|l|c|}
\hline Higher Education Institution & No. of faculty members \\
\hline Valahia University of Târgoviște & 7 \\
\hline Arts University of Târgu Mureș & 39 \\
\hline “George Enescu” Arts University of Iași & 17 \\
\hline "Gheorghe Dima” Music Academy of Cluj-Napoca & 59 \\
\hline "Ion Mincu" Architecture and Urbanism University of Bucharest & 105 \\
\hline The National Arts University of Bucharest & 98 \\
\hline
\end{tabular}




\begin{tabular}{|l|c|}
\hline The National University of Theatre and Film “I.L. Caragiale" of Bucharest & $6^{*}$ \\
\hline Total & 331 \\
\hline
\end{tabular}

* heads of departments

Source: Authors' own research.

The Civic Engagement index that we propose is composed of four sub-indexes referring to the university's relation with its interior and with the exterior community, the civism of the faculty and the civism of the students as they are perceived by the faculty we questioned.

The first sub-index measures the degree in which we can say that the university behaves as a democratic institution with respect to its faculty members and students. We entitled this sub-index the University Internal Civism Index and we based it on 19 questions pertaining to multiple categories such as: students' channels for participation in university governance and university's encouragement of their participation, students' exclusion from participating in campus life, means of inquiry related to the way the university is governed found at the disposal of students and faculty members, students and their acquaintance with their rights, transparency and democratic decision making involved in the university governing process, means of sanctioning the university management, the willingness of the university to quickly respond to student demands and the students' ability to choose their own learning path.

Besides the internal behaviour of the university, we also took into consideration the extent to which the institution acts as a responsible citizen in relation to the community in which it resides. The second sub-index is entitled University External Civism Index (UECI) and is comprised of seven questionnaire items pertaining to the following areas: the existence within the university of a research centre meant to study and promote democratic values, the promotion of civic responsibility and duties as a fundamental objective of the university, the degree to which the universities uphold local and national goals, the number of expert guest speakers and the frequency of public meetings organized within the university and the university's capacity to encourage public debate regarding political matters.

Another important social actor in this triangle we are investigating is represented by the faculty members which were the target of the next sub-index called Faculty Civism Index (FCI) measured through nine items referring to: teaching courses promoting civic responsibility, introducing social and political contemporary matters into the course materials, faculty involvement next to students in partnerships with the national and local community, encouraging students to get informed and understand their rights, taking public stances in matters of local and national concern, faculty membership in political parties or other non-governmental organizations which promote civic rights and liberties, taking part in public debates on various political affairs, and the degree to which faculty members believe they represent civic role models for their students and the extent to which they are actively involved in the community.

The fourth sub-index is called Student Civism Index and is computed by using a geometric average of the responses obtained through nine questions referring to what the faculty members believe about the students' ability to act both individually and in groups. We asked whether they seem interested in their rights as students and know the offices where they can present their problems, as well as the political and social reality of the country. Besides their interests, we also measured their perceived willingness to take 
responsibility for solving the contemporary social problems of the Romanian people and the effectiveness of their participation to university governance. The last three questions sought to find out if the students appear to be engaged in solving society's problems from the perspective of their profession, if they seem capable of informed political and civic actions. In what regards their ability to form civic coalitions we looked at the dynamics of campus opinion formation to see if there is a small group of students which dictates the campus opinions and if the students are members of networks which could become resources for their civic projects.

\section{Computed Civic Engagement Index}

According to our research, in relation to the University Internal Civism index, it resulted that, as a category, universities are considered to be slightly above average (UICI=2.41 out of 4) in what regards their behaviour as institutional vehicles for civism. We draw the conclusion that the continuous reforms have had a positive impact on the aspects related to university autonomy and governance. According to a report on academic correctitude (CUC, 2010), Romanian universities have made an impressive progress in terms of the nature and amount of the information published on the internet (activity reports, strategic plans, revenue and expenditure budget, internal regulations, function charts, procedures, academic charter, codes of ethics, students' assessment of courses and teachers and public acquisitions, salaries, and extra-revenues. This increased transparency empowers students and faculty members to understand their rights and obligations, to act in their own interests, and to acknowledge the infringements of their rights. However, five of the seven universities we have included in our study experience difficulties when it comes to institutional transparency, failing to make public the statements of assets of the university management team (which is against the law (Gologan, 2013)), and several others do not provide information regarding the components of their departments, the resumes and contact information of the faculty. These represent possible partial explanations for the fact that the index score is close to the median of the interval and is also indicative of areas for future improvement.

The faculty members expressed disapproval of the way their institutions interact with the external environment in their capacity as promoters of democratic values. The research showed that only two of the seven institutions we have analysed have at least one research centre destined for studying and promoting democracy and democratic practices and in both cases the research centre failed to serve the interests of the community, the university, the faculty members, and the students. If we look at the picture drawn by our respondents, we get the portrait of an institution which is highly involved in political matters by organizing policy debates, by participating in elections, actions which uphold the respect for the law, the principle of diversity, individual freedom, justice, equality, authority and human rights. We expected faculty members to score their university low on political involvement, but the preliminary results showed that Romanian arts universities follow their stated missions and act as enforcers of principles of lawful state, democracy and respect for the law. Thus, in the process of pursuing their mission, knowingly or unknowingly, these institutions seem to be redirecting their resources away from less controversial areas belonging to public campaigns for environmental protection, artistic representations for the disadvantaged and volunteering in different social actions. 
Table 2 - Perception of university actions targeting an involvement in the community

\begin{tabular}{|l|l|}
\hline Highest scoring items & Lowest scoring items \\
\hline Policy debates & Actions that uphold truthfulness \\
\hline Actions that support the respect for the law & Actions that support tolerance \\
\hline Actions that uphold diversity & Actions that uphold self-esteem \\
\hline Elections & Actions that uphold volunteering \\
\hline Actions that support freedom & Actions that uphold patriotism \\
\hline Actions that uphold human rights & Actions that uphold petitioning \\
\hline Actions that uphold justice & Actions that uphold the right to a private life \\
\hline Actions that & Actions that uphold philanthropy \\
\hline Actions that uphold authority & \\
\hline
\end{tabular}

Source: Authors' own research.

In regards to their own civic responsibility, faculty members have scored themselves rather low, the average of the Faculty Civism Index being 2.09 out of 4, although they perceive themselves as role models for their students in terms of civic engagement. Most often, they include current social and political information in their discourses and they actively engage in partnerships with the local and the national communities. Similar findings were reported by Cantaragiu et al. (2014). The lowest scoring items were related to the membership in political parties and or non-governmental organizations that promote civil rights and liberties, and the engagement in actions meant to stimulate students to understand their rights.

Lastly, we present the current situation of the level of student civic engagement as perceived by arts faculty members. We take the score (2.22 out of 4) as representative of the level of dissatisfaction of faculty members with their students' behaviour as responsible citizens inside and outside the university. This shows that they adhere to the general opinion that today's young generations do not have at their disposal the necessary resources to become active citizens. A study published by IMAS (2012) showed that Romanian youngsters seldom engage in commentaries on the socio-political reality, except for the problems they face when trying to integrate on the job market. However, the fact that students received very low scores might also be explained by a biased perception that is grounded in a type of social interaction in which students do not regard faculty members as role models or mentors, but as "dispensers" of knowledge and skills. Thus, faculty members might not get the chance to come into contact with the civic side of students' lives and this could lead to a distorted view of the students' involvement in contemporary society.

\section{Conclusions}

The Civic Engagement Index that we have introduced presents a multi-faceted view of universities' various relations with their communities and it is useful in benchmarking analysis due to its possibility to be expressed as the geometric average of the four subindexes. In this type of analyses we compare side-by-side each of the four indexes and select the areas which show the greatest discrepancies as targets for improvement. In our preliminary results, The Valahia University of Târgoviște received the highest overall score, while the "Gheorghe Dima" Music Academy of Cluj-Napoca received the lowest score. Our calculations have shown that the greatest difference between sub-indexes was found under the Faculty Civism Index. As means to enhance the degree of civic orientation of faculty members, we suggest that the Music Academy could design and popularize civil 
participation guides (as The Babeș Bolyai University has done) or a civil responsibility declaration, organize civic responsibility classes for faculty members and students and introduce service learning classes. Service learning refers to "[a] method under which students learn and develop through active participation in thoughtfully organized service experiences that meet actual community needs, and which are coordinated with a formal educational institution) to address and support an academic curriculum (Crews, 2002; Battistoni, 2017). We end by citing Sullivan (1996) who says that the most critical challenge posed to a university with respect to civic mission is whether "[higher education] has the ability and the will through leadership, institutional design, teaching and research, in creating a new form of intellectual life for the public good" (p. 18).

\section{Bibliography}

Battistoni, R. M. (2017). Civic engagement across the curriculum: A resource book for service-learning faculty in all disciplines. Stylus Publishing, LLC.

Bejinaru, R. (2017). Universities in the knowledge economy. Management Dynamics in the Knowledge Economy, 5(2), 251-271.

Bowen, H. R. (1997). Investment in Learning: The Individual and Social Value of American Higher Education, (2nd ed.), Johns Hopkins University Press, Baltimore.

Boyer, E. L. (1990). Scholarship Reconsidered: Priorities of the Professoriate, Carnegie Foundation for the Advancement of Teaching, Princeton, NJ.

Bratianu, C., \& Stanciu, S. (2010). An overview of present research related to entrepreneurial university. Management \& Marketing, 5(2), 117-134.

Cantaragiu, R., Paunescu, C., \& Hadad, S. (2014). The social impact of university entrepreneurship in Romania: Is the institutional discourse replicated or adapted? Management \& Marketing, 9(4), 403-422.

Crews, R. J. (2002). Higher education service-learning sourcebook. Greenwood Publishing Group.

Dima, M.A. and Vasilache, S. (2016). Trends in the internationalization of European higher education in a convergence perspective. Management \& Marketing. Challenges for the Knowledge Society, 11(2), 449-457.

Dewey, J. (1916). Democracy and education. In The middle works of John Dewey, Vol. 9, Carbondale, IL: Southern Illinois University Press.

Fish, S. (2003), "Aim Low," The Chronicle of Higher Education, 16 May 2003, Available at: http://chronicle.com/prm/weekly/v49/i36/36c00501.htm (18 October 2016).

Fish, S. (2003), "Save the World on Your Own Time," The Chronicle of Higher Education, 23 January 2003, Available at http://chronicle.com/jobs/2003/01/2003012301c.htm (3 March 2015).

Fish, S. (2003), "The Same Old Song," The Chronicle of Higher Education, 11 July 2003, Available at: http://chronicle.com/prm/weekly/v49/i44/44c00201.htm (23 March 2015).

Gaffikin, F., \& Morrissey, M. (2008). A new synergy for universities: Redefining academy as an'engaged institution'. Education, Citizenship and Social Justice, 3(1), 97-116.

Gauca, O. and Hadad, S. (2013). Does civil society create social entrepreneurs?. Annals of The University Of Oradea, Economic Science Series, 22(1), 650-657.

Gologan, D. (2013) Vezi care sunt cele 21 de universitati care ascund declaratiile de avere, Available at http://www.romaniacurata.ro/articol-3939.htm 
Gottlieb, K., \& Robinson, G. (2004). Integrating Civic Responsibility into the Curriculum. Community College Journal, 74(3), 25-26.

HackerNoon (2017). Are civic hackathons impactful? Available online: https://hackernoon.com/are-civic-hackathons-impactful-e575c401228a [20 December 2016].

Johnson, P., \& Robinson, P. (2014). Civic hackathons: Innovation, procurement, or civic engagement?. Review of Policy Research, 31(4), 349-357.

Kline, A. D., (2005) On what's Fishy About Civic Responsibility, Teaching Ethics, Fall.

Korn, M., \& Voida, A. (2015, August). Creating friction: infrastructuring civic engagement in everyday life. In Proceedings of The Fifth Decennial Aarhus Conference on Critical Alternatives (pp. 145-156). Aarhus University Press.

Nastase, M. \& Valimareanu, I., (2017), 'Building a Strong Organizational Culture for Sustainable Development of Tourism Companies', Review of International Comparative Management 18, 122 - 130.

Ontario. Royal Commission on Education in Ontario. (1950). Report of the Royal Commission on Education in Ontario. Toronto: King's Printer.

Pancer, S. M. (2015). The psychology of citizenship and civic engagement. Oxford University Press, USA.

Soare, I., Cristache, N., Dobrea, C.R. \& Nastase, M., 2017, 'The rural touristic entrepreneurship - new opportunities of capitalizing the rural tourist potential in the context of durable development', European Journal of Sustainable Development 6, 231-252.

Stewart, T. (2012), Honours service-learning and civic responsibility, The International Journal, of the First Year in Higher Education,3(1), 49 - 60.

Sullivan, W. M. (1996). The public intellectual as transgressor. Higher Education Exchange, $1,17-22$.

The Higher Education and Democratic Culture: Citizenship, Human Rights and Civic Responsibility Declaration, Strasbourg, 2006.

Thornton, C. H., Jaeger, A. J., (2007), A new context for understanding civic responsibility: relating culture to action at a research university, Research in Higher Education, 48(8), $993-1020$.

Van Ingen, E., \& Bekkers, R. (2015). Generalized trust through civic engagement? Evidence from five national panel studies. Political Psychology, 36(3), 277-294.

VanWynsberghe, R., \& Andruske, C. L. (2007). Research in the service of co-learning: Sustainability and community engagement. Canadian Journal of Education, 30(1), 349-377.

Vizitiu, C., Agapie, A., Paiusan, R., Hadad, S. \& Nastase, M., (2018), "Adapting corporate entrepreneurship assessment instrument for Romania", South African Journal of Business Management 49, 1-11, forthcoming. 